\title{
Negotiations in the Care of Chronically Ill Children: Building Possibilities in a Setting of Uncertainty
}

\section{| ${ }^{1}$ Hermínia Guimarães Couto Fernandez, ${ }^{2}$ Martha Cristina Nunes Moreira I}

Abstract: Interested in exploring the construction of the negotiations present in the decision relationships in complex chronic care in pediatric outpatient settings, we approach Anselm Strauss and the concept of negotiated order and Annemarie Mol with the concept of decision logic associated with Latour actor-network theory. We used an ethnographic perspective of health research in the pediatric and stomatherapy outpatient clinics of a hospital located in the city of Rio de Janeiro, from July to December 2017. The interpretation of the field converged to two major axes: diagnosis and therapeutic itineraries, where care was performed through negotiation networks. These concerned the organization of the lives of people related to this care. This whole negotiation process took place in a hybrid scenario, marked by blurring across borders, where caregivers constantly negotiated the recognition of their children. Depending on the spaces and times of interaction, the actors moved through different identities, in a negotiation between how they recognized themselves and how they were recognized by people in complex chronic care. Negotiations in the observed care relationships took place between the uncertainties inherent to the health condition and the possibilities of living with that diagnosis.

> Keywords: Negotiating; child care; chronic disease; anthropology, cultural.
${ }^{1}$ FIOCRUZ. Rio de Janeiro-RJ, Brazil (coutofernandez@hotmail.com). ORCID: 0000-0002-5111-6391

2 FIOCRUZ. Rio de Janeiro-RJ, Brazil (marthacnmoreira@gmail.com). ORCID: 0000-0002-7199-3797

Received on: 07/12/2019

Approved on: 15/03/2020

Reviewed on: 13/10/2021 


\section{Introduction}

Children with complex chronic health conditions (CCHC) are occupying increasingly more hospital beds and consuming resources of the Brazilian public health system (SUS) (DUARTE et al., 2012; GAVAZZA et al., 2008; MOREIRA et al., 2015; MOURA et al., 2016). This group comprises children dependent on technology, specialized health services, living with complex pathologies, and carrying multiple impairments (COHEN et al., 2011; FEUDTNER; DIGIUSEPPE; NEFF, 2003). In Brazil, public health actions to adapt the SUS to the epidemiological reality of increasing chronic diseases include adults and older adults, but barely recognize children with $\mathrm{CCHC}$, which has led to discussions about implementing health actions geared to these children to improve their care (MOREIRA; CUNHA; MELLO, 2016).

These children are now more visible in hospitals, where they grow, acquire skills, explore their bodies, and where decisions about their care are negotiated (MOREIRA; CUNHA; MELLO, 2016). Depending on technologies (RUSSELL; SIMON, 2014), they need their family caregiver to recognize instabilities and monitor them, in a mix, which accesses proximity in common care and a close perspective on the technician to ensure timely action to avoid risks (MOREIRA; CUNHA; MELLO, 2016)

After de-hospitalization, these children may become part of hospitalization routines and pediatric outpatient clinics, homes, and schools. This presence can contribute to cultural shifts, and the necessary change in the perspectives and professional training in which the suffering of all involved is enhanced, due to the challenges of working with them (CASTRO; MOREIRA, 2019; MOREIRA; CUNHA; MELLO, 2016).

Technology-dependent children with CCHC followed up on an outpatient basis represent a particular group. Because they are at home, their caregivers have more decision-making autonomy than when hospitalized, although these decisions are built and negotiated in pediatric outpatient clinics. Conflict is part of this decisionbuilding process, which can often turn the so-called "shared care" into a tool for convincing others to do what is best for them, without discussing the clinical scene's asymmetries (FERNANDEZ et al., 2019). 
Here, we highlight the sociocultural aspects involved in negotiating decisions in the experiences of children and adolescent illnesses, considering what is at stake for people when they decide, which means activating values, beliefs, and ways to understand how to deal with and elaborate the negotiation of decisions in the care of children and adolescents with complex chronic health conditions (KLEINMAN; BENSON, 2006).

This paper aims to analyze the negotiations in complex pediatric care relationships in outpatient care settings. We were interested in knowing how the marks of the children's health condition interfere in the negotiation of care decisions and analyzing how, when, and what the stakeholders involved in the care of these children negotiate.

\section{Negotiations in outpatient care for children with CCHC}

Anselm Strauss, Annemarie Mol, and Bruno Latour became key authors to build interpretive paths about the negotiations in the decisions built in the outpatient care for children with CCHC.

The concept of negotiated order, according to Strauss, concerns the relationship between the rigid structure of hospitals, underpinned by norms and laws, and agreements made outside these norms, which take place in defense of the interests of the stakeholders involved and give rise to new rules, which are informal (RANGEL, 2007; STRAUSS, 1978; STRAUSS et al., 1982). Our analysis, therefore, is anchored in the perspective of symbolic interactionism about the negotiations that take place in social systems, in which hospitals are also included (LALLEMENT, 2004; MARTINS, 2013). Symbolic interactionism refers to the constant process of social interaction that takes place between individuals, and in this interaction, they inspire actions and are also inspired, assigning meaning to the plot they experience, in relationships that are not egalitarian and are influenced by more significant structures, and they may also become part of them, producing other orders (GASTALDO, 2015; JOSEPH, 2000; LALLEMENT, 2004).

Understanding that the social order is constantly built through negotiations made in the interactions between subjects, Strauss illuminates the social world of the hospital, an apparently rigid institution, but also subject to this dynamic. The hospital's social world is constituted by negotiations between the actors involved 
(workers, patients, and visitors), who also contribute to (re)define their social situation through their attitudes (LALLEMENT, 2004; MARTINS, 2013). Thus, individuals do not suffer social facts but produce them continuously, where they conceive and build their actions when interpreting the situation in which they find themselves, creating their viewpoints and representations (LALLEMENT, 2004; MARTINS, 2013).

We believe that talking about a negotiated order in the care of children with $\mathrm{CCHC}$ leads us to the challenge of addressing stigmatization, meanings, and care. As for stigmatization, these children's marks are both physical and symbolic and built on social interaction, when children with $\mathrm{CCHC}$ are recognized as different by other people., in this dynamic, when creating norms, Goffman (GOFFMAN, 1980) believes that social groups identify these children as abnormal, and they are then assigned a social role that they should play. They may or may not fulfill these normative expectations. When their attributes are incompatible with their stereotype, these children can be reduced to "spoiled or diminished" people. Thus, in this dynamic, when negotiating with the so-called deteriorated identities and based on the relationship with stigmas, social groups call for a discrepancy between virtual (which the other attributes based on manifest attributes) and real (effectively owned attributes) social identities.

Living in dependence of technological devices, for example, can be a stigma of a complex health condition and have several, different meanings for each child and their family. It is essential to bring clinical guidelines and consensus and consider the vast field of meanings (VENTURINI, 2010). Understanding care as a philosophical category of being in the world (ANÉAS; AYRES, 2011; AYRES, 2004a, 2004b), negotiating the decision is not restricted to aspects of medical treatment and expands to other approaches to the life of an individual with CCHC: for example, if the individual goes home, or for Justice to assert his/her rights, or if he/she will manage to be enrolled in school. Taking care of people requires considering the projects for that life, what that subject understands by life and what he/she wants from life (ANÉAS; AYRES, 2011; AYRES, 2004a, 2004b).

As for the rationale associated with negotiating decisions, Mol characterizes it as choice and care. Regarding choice, professionals will present facts and information to the patients who will make their choice based on their values. This choice is between variables that seem fixed, and they will weigh the pros and cons, "subtracting and 
adding", to reach a conclusion. This decision is restricted to the clinical encounter, and the professional has to implement care (MOL, 2008, 2013).

However, Mol emphasizes that the care provided to people with chronic diseases is not about choices but the organization of their lives in practice, giving rise to decisions based on the logic of care. In these decisions, facts and values are intertwined, the variables are not fixed, and the choice does not result from a mathematical sentence but from continuous craftsmanship, which is not restricted to the moments of encounter, and, after each decision, another one follows. It is not up to the professional to implement the decision but to propose it and, if it does not work out, replace it with new proposals (MOL, 2008, 2013).

Considering that the negotiation of decisions in the care of complex chronic children includes the management of the technological apparatus, access to it, the mediations and changes it produces in the bodies, and the subjective decision negotiation processes, we dialogued with Latour (LATOUR, 2012), as it becomes crucial to consider the connections between human and non-human actors. The idea of actor presented here follows Latour's perspective of actant: everything human or non-human - that generates an action that produces effects in the flows, circulations, and alliances in which they are involved. Thus, they interfere and suffer continuous interference (LATOUR, 2012).

\section{Methods}

This paper is an excerpt from the doctoral research approved at CEP under CAAE 65417317.2.0000.5269, Opinion no 2.161.245, where a systematic participant observation was conducted by the first author of this work, following the ethnographic perspective of the health research in hospital environments (CAPRARA; LANDIM, 2008) (MENEZES, 2000, 2004) (DUARTE; MOREIRA, 2011) (BARSAGLINI, 2011). It aims to understand, as comprehensively as possible, the group or organization under study, analyzing, through a dense description, its singularities, interactions, and institutional, ideological, or cultural rationale that anchors its actions and how they correlate with the broader social context (GEERTZ, 1989) (BECKER, 1994). Seeking this perspective, we sought a theoretical abstraction (GEERTZ, 1989) and an apprehension of the procedures, which allowed us to transcend the initial theoretical scheme and take as reference the "experienced concrete" (MAGNANI, 2002). 
Interpersonal communication was added to the researcher's ability to establish relationships of mutual trust and mutual and long-term understanding (MAGNANI, 2002; VELHO, 1999). To this end, it was necessary to dedicate time and skill to explain the objectives and legitimacy of the work, generating voluntary adherence (FOOTE-WHYTE, 1980; VALLADARES, 2007). In a space where the first author had already established her identity as a doctor, it was necessary to negotiate not the field entry but the "new" role of the researcher. She had to remove her lab coat, which involved time and discipline to look at her typical work environment, its routines and actors, looking for surprises, other focuses. Her presence there now, in an observant posture, in the pediatric outpatient clinic, was initially questioned: "what are you doing there in disguise?" asked a professional in front of this "new researcher" sitting in the waiting room without a coat, observing. To each question of estrangement, the answer came in the form of explaining the estrangement and taking the opportunity to present the research and the newly established place for now. The feeling that the function could be the "incarnation of a spy's disguise" was also present. Moreover, the playful and curious hues colored the scene, together with the estrangement of the new presence of the "doctor-researcher". Once this fear was perceived as an exercise in reflexivity generated in the writing spaces of the field diary and research supervision, it was necessary to indicate the characteristics of this research. In other words, this place of looking at everyone, whether health professionals, cleaning workers, families, and children, as an observer in waiting rooms, was the novelty that triggered such reactions. After a while, no one asked anything anymore, and they were already talking to the "doctor-researcher", saying, "it's your doctorate, right?"

Bonet (BONET, 2004) discusses the medical symbolism of the lab coat in ethnography performed in a hospital. Being an anthropologist and not belonging to that environment of professional practice that he observed, he had to wear his lab coat to be accepted in this environment. However, in this research, it was not necessary to negotiate field entry, but switching position: temporarily ceasing to be the doctor was required to build the researcher. Such consideration reminds Da Matta (DA MATTA, 1978) in what he called the self-exorcism movement, in which, in the case of this research, where native practices of the profession were observed, taking off the lab coat meant "taking off the cap of a class member... to be able... to 
estrange some familiar social rule and thus discover... the exotic in what is petrified within us..." (DA MATTA, 1978) (p. 28-29)

In the case of data production techniques, we used participant observation as the central technique (CAPRARA; LANDIM, 2008; LAPLANTINE, 1991). The external (waiting room, weight room, procedure room, and secretariat) and internal spaces were observed, as they are places where several decision-making negotiations for the care of these children occur.

The diary was the field recording instrument, totaling 41 notes. The 12 semistructured interviews with family members were essential to deepen the research questions (CAPRARA; LANDIM, 2008; MINAYO, 2011). They were digitally recorded and fully transcribed. Eight health professionals were also interviewed in the original work, but these will not be addressed in this paper.

We started from the centrality of the complex chronic health condition in the lives of children and adolescents and, by extension, in the care of their families, per Cohen's definition (COHEN et al., 2011), to build the qualitative research sample. Thus, choosing the families included the possibility of considering several types of technological dependence that promote other negotiations of decisions related to technology-dependent child care, such as changes in medications, changing doctors, opting for technology changes due to complications or clinical, or even social indications. Thus, family members over 18 years of age awaiting care for their children at the stomatherapy or pediatric outpatient clinics participated in the interviews. The interviews started three months after the beginning of the field and were interspersed with participant observations from the external and internal spaces of the clinics. The study was carried out in the pediatric and stomatherapy clinics of a tertiary, high-complexity outpatient and hospital unit linked to the Brazilian Unified Health System, dedicated to caring, teaching, and research on the health of women, children, and adolescents. The survey was conducted from July to December 2017.

The field was closed when the material constructed was sufficient to answer the research questions, and the ideas began to repeat themselves. The findings were analyzed and interpreted following the perspective of the conceptual, theoretical framework, triggering the vision of symbolic interactionism (MARTINS, 2013), articulated with study objectives and questions and empirical data. 
We analyzed the empirical material to understand beyond what has been described and analyzed, from semantic to sociological structures, articulating the field with its determinants (GOMES, 2011). Thus, in the first phase, we organized the collection based on the questions and objectives of the research and characterized, by the verification of its recurrence in the studied field, a map of themes: social navigation, the estrangement of the researcher's role, and the place of adolescents in the field, which were further analyzed in the interviews, giving rise to five more themes: marks, negotiations about marks, temporalities of the actors in relationships, negotiations about technologies, choices in the management of technologies and stance of family members and health professionals in decisions. Then, we arrived at the meanings derived from these interview themes (Box 1). These meanings converged into two principal axes: diagnosis and therapeutic itinerary $(\mathrm{TI})$, addressed in the next section.

Box 1. Relationship between interview themes and derived meanings

\begin{tabular}{|l|l|}
\hline \multicolumn{1}{|c|}{ Synthesis ideas } & \multicolumn{1}{|c|}{ Derived ideas } \\
\hline Marks & $\begin{array}{l}\text { What are the diagnoses, their cause and technologies } \\
\text { in use }\end{array}$ \\
\hline Negotiations about marks & $\begin{array}{l}\text { In general decisions: who provides care, employment, } \\
\text { livelihood, network, relatives, school, medical follow- } \\
\text { up and rehabilitation, hospitalizations and discharges, } \\
\text { challenges and difficulties (expectations, plans, and } \\
\text { fears) regarding the disease }\end{array}$ \\
\hline Negotiations about technologies & $\begin{array}{l}\text { Who takes care of devices, complications, reason for } \\
\text { technology }\end{array}$ \\
\hline Actors' temporalities in relationship & Interference of time in care decisions \\
\hline Choices in managing technology & $\begin{array}{l}\text { Choices: how is the relationship between people } \\
\text { family, school, network, hospital, association and } \\
\text { rights) regarding care and how it is built in this } \\
\text { relationship. Since then, we identified the mother as } \\
\text { the main caregiver, and the focus was her relationship } \\
\text { with the other actors. }\end{array}$ \\
\hline $\begin{array}{l}\text { Stance of relatives and health professionals } \\
\text { regarding decisions }\end{array}$ & $\begin{array}{l}\text { In the relationship between relatives and health } \\
\text { professionals, how (mode: leadership, courage, } \\
\text { support, and imposition), what (technology, other } \\
\text { care, hospitalization, discharge, and birth) and who } \\
\text { (professional: nursing technician, nurse, doctor/ } \\
\text { relatives: mother, father, child, and family) decides }\end{array}$ \\
\hline
\end{tabular}




\section{Results/Discussion}

The children whose family members were interviewed are characterized in Box 2. Their ages ranged from 6 months to 12 years and had different diagnoses and marks that were symbolic and revealed in their appearance. Some references to their conditions made by their relatives were: "very still", showing tremors, losing their breath, "they turned purple", they had "dead meat". Others had a sequence of marks that together formed a "syndrome", and one had, according to his mother, a "modified genetic code".

Technology dependence started very early, in the first days of life. Of varied nature, children who depended on gastrostomy and wheelchairs were predominant.

The interviewed subjects were anonymized by the order of interviews, where (M) was the mother, $(\mathrm{P})$ the father, followed by the Arabic numerals corresponding to the order of interviews. As twelve family members were interviewed, we decided to name their children according to the relative month of the year, which facilitated the correspondence between family members and children. For example, I call the child February in interview 2.

Box 2. Characterization of the children in the study

\begin{tabular}{|c|c|c|c|}
\hline $\begin{array}{l}\text { CHILD } \\
\text { (Gender) }\end{array}$ & AGE & DIAGNOSIS & TECHNOLOGY (AGE) \\
\hline JANUARY (male) & $10 y$ & Cerebral palsy & GTT (2y) + WC (3y) \\
\hline FEBRUARY (female) & 1y $10 \mathrm{~m}$ & $\begin{array}{l}\text { PMT and PSHD-derived } \\
\text { convulsion }\end{array}$ & $\begin{array}{l}\text { GTT (6m up to } 1 \mathrm{y} 8 \mathrm{~m})+\mathrm{GCF} \\
(1 \mathrm{y} 8 \mathrm{~m})\end{array}$ \\
\hline MARCH (male) & $2 y$ & Patau's syndrome & $A C(1 \mathrm{y})+\mathrm{WC}(3 \mathrm{~m}$ ago $)$ \\
\hline APRIL (female) & $7 \mathrm{~m}$ & Undiagnosed syndrome & GTT (2m) \\
\hline MAY (female) & $10 y$ & $\begin{array}{l}\text { Merosin-negative congenital } \\
\text { muscular dystrophy }\end{array}$ & $\begin{array}{l}\text { Insulin (at birth to } 2 \mathrm{~m})+ \text { GTT } \\
(1 \mathrm{y})+\text { WC (4y) }\end{array}$ \\
\hline JUNE (female) & $6 \mathrm{~m}$ & Hydranencephaly & VPS $(3 \mathrm{~d})+$ changed VPS $2 \mathrm{X}$ \\
\hline JULY (female) & $5 y$ & $\begin{array}{l}\text { Rare syndrome } \\
\text { (Aicardi) }\end{array}$ & AC $(1 \mathrm{~m})+\mathrm{WC}(3 \mathrm{~m}$ ago $)$ \\
\hline AUGUST (female) & $3 y$ & $\begin{array}{l}\text { Hydrocephalus and Dandy } \\
\text { Walker Syndrome }\end{array}$ & $\begin{array}{l}\text { VPS }(15 \mathrm{~d})+\text { GTT }(3 \mathrm{~m})+\text { WC } \\
(4 \mathrm{~m} \text { ago })+\text { changed VPS } 4 \mathrm{X}\end{array}$ \\
\hline
\end{tabular}

to be continued... 


\begin{tabular}{|l|l|l|l|}
\hline \multicolumn{1}{|c|}{$\begin{array}{c}\text { CHILD } \\
\text { (Gender) }\end{array}$} & \multicolumn{1}{|c|}{ AGE } & \multicolumn{1}{|c|}{ DIAGNOSIS } & \multicolumn{1}{|c|}{ TECHNOLOGY (AGE) } \\
\hline SEPTEMBER (female) & $12 \mathrm{y}$ & Cloacal exstrophy + MMC & $\begin{array}{l}\text { CLT (at birth) + MTF (4y) + } \\
\text { WC (2y) }\end{array}$ \\
\hline OCTOBER (male) & $3 \mathrm{y}$ & Caustic esophageal stenosis & GTT (2y) \\
\hline NOVEMBER (female) & $8 \mathrm{y}$ & $\begin{array}{l}\text { GTS, intestinal atresia, short } \\
\text { bowel }\end{array}$ & $\begin{array}{l}\text { Ileostomy (due to atresia) at } \\
\text { birth }\end{array}$ \\
\hline DECEMBER (female) & $8 \mathrm{y}$ & Cystic fibrosis & $\begin{array}{l}\text { Ileostomy (10 d to 9 m) + GTT } \\
(1 \text { month ago })+\text { medications }\end{array}$ \\
\hline
\end{tabular}

Captions: $y=$ years; $m=$ months; $d=$ days; $G T T=$ gastrostomy; $\mathrm{WC}=$ wheelchair; $P M T=$ prematurity; PSHD: pregnancy-specific hypertensive disease; GCF: gastrocutaneous fistula; AC: anticonvulsant; VPS: ventriculoperitoneal shunt; MMC: myelomeningocele; CLT: colostomy; MTF: Mitrofanoff; GTS: gastroschisis

The caregivers (Box 3) were predominantly mothers, half of whom were black, who had low income despite some schooling.

Box 3. Characterization of interviewed relatives

\begin{tabular}{|l|l|l|l|}
\hline \multicolumn{1}{|c|}{$\begin{array}{c}\text { RESPONDENT } \\
\text { (AGE) }\end{array}$} & \multicolumn{1}{|c|}{ INCOME } & \multicolumn{1}{|c|}{ SCHOOLING } & \multicolumn{1}{c|}{$\begin{array}{c}\text { SKIN } \\
\text { COLOR }\end{array}$} \\
\hline (1) mother, 41y & $\begin{array}{l}\text { Unemployed mother } \\
\text { Receives BPC }\end{array}$ & HS & white \\
\hline (2) mother, 39y & $\begin{array}{l}\text { Unemployed mother. } \\
\text { Receives BPC. Grandmother's financial } \\
\text { aid. }\end{array}$ & ES & brown \\
\hline $\begin{array}{l}\text { (3) mother, 47y } \\
\text { (4) mother, 39y + } \\
\text { father, 49y }\end{array}$ & $\begin{array}{l}\text { Father and mother employed, } \\
\text { Statutory. No BPC }\end{array}$ & Higher Education & brown \\
\hline (5) mother, 40y & $\begin{array}{l}\text { Unemployed mother, } \\
\text { Receives BPC. }\end{array}$ & $\begin{array}{l}\text { Higher Education, } \\
\text { Higher Education }\end{array}$ & white \\
\hline (6) mother, 29y & $\begin{array}{l}\text { Mother and father unemployed, No BPC, } \\
\text { live on father's side jobs }\end{array}$ & Higher Education & white \\
\hline (7) mother, 49y & $\begin{array}{l}\text { Unemployed mother. Father working. } \\
\text { Does not receive BPC. Income BRL 1,500 }\end{array}$ & HS & white \\
\hline
\end{tabular}

to be continued... 


\begin{tabular}{|l|l|l|l|}
\hline \multicolumn{1}{|c|}{$\begin{array}{c}\text { RESPONDENT } \\
\text { (AGE) }\end{array}$} & \multicolumn{1}{|c|}{ INCOME } & \multicolumn{1}{|c|}{ SCHOOLING } & \multicolumn{1}{c|}{$\begin{array}{c}\text { SKIN } \\
\text { COLOR }\end{array}$} \\
\hline (8) mother, 26y & $\begin{array}{l}\text { Mother and father unemployed, with } \\
\text { BPC and father has side jobs }\end{array}$ & ES & brown \\
\hline (9) mother, 39y & $\begin{array}{l}\text { Mother is a house cleaner and father is } \\
\text { working. } \\
\text { Receives BPC } \\
\text { Household income BRL 2,000 }\end{array}$ & ES incomplete & black \\
\hline (10) father, 23y & $\begin{array}{l}\text { Father and mother unemployed. No BPC, } \\
\text { mother with Family Aid. Live on side jobs }\end{array}$ & ES incomplete & black \\
\hline (11) mother, 27y & $\begin{array}{l}\text { Mother unemployed. Father working. } \\
\text { Receives BPC. Income is two minimum } \\
\text { wages. }\end{array}$ & HS incomplete & black \\
\hline $\begin{array}{l}\text { (12) mother, 41y + } \\
\text { father, 47y }\end{array}$ & $\begin{array}{l}\text { Mother self-employed, working, and } \\
\text { father operations technician, employed. } \\
\text { Income BRL 5,000. No BPC. }\end{array}$ & HS, HS & white \\
\hline
\end{tabular}

Captions: $y=$ years; BPC= Continuous Cash Benefit (LOAS); HS= High School; ES= Elementary School

While with varying diagnoses, the children in this research had everyday health needs and were raised by medical devices that save lives and create demands. They encompassed health conditions of chronic evolution, with complex characteristics, with countless dependence. These health conditions had implications for their lives and were significant in their construction, social recognition, and trajectories of family care and sociability. In an open network of connections between different human and non-human actors, they built the negotiations in their care (LATOUR, 2012).

\section{Negotiations in the diagnosis}

“... the diagnosis... lack of oxygenation... in the brain... it's a delay she has. This is was they explained to me there when she was hospitalized. That what she would have ... see with time ... So today she can see that it is the not walking." (M2)

Family members and health professionals were looking for a diagnosis, and, upon classifying the child after obtaining it, they began to negotiate with their prognoses and treatments. Thus, we observed negotiations with the children's marks in the various diagnoses, corresponding to their health condition and the need for technology. The diseases and diagnoses observed in the studied children came into 
existence a few years ago, and this did not happen because they were discovered, as natural categories waiting to be revealed (JUTEL, 2009; ROSENBERG, 2002). Jutel and Rosenberg analyze the relationship of the biomedical industry and the transformations in the science of care, surgical techniques, and biomedical engineering, with the "emergence" of these health conditions, which cover a variety of diseases with chronic evolution, complexity, and dependence in common, thus conjuring that those involved with these new health conditions share experiences of living with them (ALVES, 2016).

\footnotetext{
"She discovered it in morphological (ultrasonography) and, since then, we were in tension, thinking it was the end of the world... Then after she was born, we took it one day at a time, and we got used to it. "(M6)
}

The diagnoses also referred to negotiations with temporalities and were performed as milestones, where their search was the onset of the children's and their families stories. They related to time as a prerogative of care learning, and a future was projected through them. The diagnosis of their children meant, for parents, among other things, the possibility of being able or not to see their children grow and develop, besides all the fear around this setting; managing dependence; whether or not they are worthy of love and respect; gaining or losing rights, having or not having access to services and status, and annulment or leadership. Managing the illness of these children as a social phenomenon involved negotiating the meanings of the diagnoses among those involved (ROSENBERG, 2002).

As for the need for technology, negotiations with temporalities were related to the authorization to install a technological device, reversibility or not of this device, and the race against time to reach hospitals when in difficult times.

The Nursing technician tells the parents that the emergency is if the cuff pops, and the probe goes out. That's because the hole can close... it's no big deal; it's like she was vomiting. You are going to put the probe tip and go to the hospital (field diary, p.80-81, 18/10/17)

The devices facilitated the lives of these children with malformations and disabilities, who, with the concomitant existence of extreme but necessary and proper poles - such as nature and technology (HARAWAY et al., 2013) - were able to go home and start a new care trajectory. We were surprised by the observations and interviews of the adolescents' relatives because, despite the predictions of a short lifespan, their children were growing up and planning their lives. 
“...I didn't want her to date someone...because September doesn't have a vagina, doesn't have an anus. I stay focused a lot like that. Some girls already have sex. I don't know what September would be like. She is horny. (M9)

Values were assigned to September's malformed physical body, and the girl related to the world through this body, negotiating her sexuality. Through subjects such as study, work, sex, dating, we could see the growth of these children with chronic diseases and the possibilities they created to live with and through their disabled bodies. These issues bring the humanity of these modified bodies with special needs, but which also face the same issues of people without the disease, which are issues specific to human nature (GOODLEY; RUNSWICK-COLE; LIDDIARD, 2016; MOREIRA; CUNHA; MELLO, 2016; PAEZ; MOREIRA, 2016).

Addressing the diagnosis means thinking about names of diseases and health conditions and how these names are arrived at and how they were culturally built, their social repercussions, and how they are negotiated between the various actors involved (JUTEL, 2009). Considering that this negotiation is not previously established, but takes place in diagnosis and care (MARTIN; SPINK; PEREIRA, 2018; MOL, 2002, 2008), it leads to the existence of "new children" and "new mothers", who know a lot about their children and live with their health condition even before birth (MOREIRA; CUNHA; MELLO, 2016). They start early, together with their children, a "sick career" and thus know them in detail, becoming excellent observers and developing sensitivity to their health instabilities (MOREIRA; CUNHA; MELLO, 2016).

\section{Negotiations in the therapeutic itineraries}

The TIs were constituted by negotiations that involved both the diagnosis and the pilgrimage seeking care, involving geographic trajectories and meanings. Freidson's discussions contribute to the conceptions of the therapeutic itinerary. By being socially defined as sick, this author believes that the individual starts a set of practices seeking treatment. Through this itinerary, people assume the role of a sick person, having experiences with various treatment agencies, where each assigns its therapeutic notions, generating different status for the sick person (ALVES, 1993).

In TIs, negotiations involved transformation, in which family members reinvented themselves, and through tricks, solutions that were not foreseen, circumvented what was socially established for them, using the knowledge acquired in practice. 


\begin{abstract}
"We have our tricks. The intestine is draining water... Once I took a piece of thin cotton and wrapped it around the intestine... I put a layer of the thin paste and put the bag... The cotton sucks. So, there's time for you to put the bag, and it sticks fast, without undermining. (M11)
\end{abstract}

Another "trick" possibility was to get closer to professionals who showed bonds of the same social belonging within hospitals, where power was defined not by knowledge but by proximity. We observed that mothers on their way to take care of their children made use of the technical knowledge acquired in living and researching the internet and the networks of relationships to position themselves in the negotiations with health professionals:

When the nursing technician punctures the girl's vein, she says she is a great friend of her mother. "Her other son was hospitalized here for a long time, and we, after that, established a lasting friendship", says the technician (Field diary, p.20, 19/07/17)

The "tricks" became strategies to face and react to the pilgrimages, and even the violation of the right to access health care in the stories studied. Such pilgrimages are documented in the literature when studying the trajectories of families of children with chronic illness experiences (FAVERO-NUNES; SANTOS, 2010). It is also worth mentioning the identification of rights violation components, characterized as institutional violence, when the itinerary is linked to population groups associated with the ethnicity/skin color marker, in the case of quilombolas (SIQUEIRA et al., 2016). We believe that "tricks" are something that can be dialogued with the debate undertaken by Moreira, Cunha, and Mello (2016) when they discuss the "patient career" that these children build.

Using Strauss' theory of negotiated order (STRAUSS, 1978) with Roberto Da Matta's (PINTO, 2010; PRADO, 2016) "fix" theory, we could see that the negotiation in the observed environment was comprehensive. The laws, rules, protocols, that is, the system's structural factors, while fixed, were always valid and exposed to personal relationships. The negotiation between the system's structure and the several interests of those involved in the decisions to be taken was greatly influenced by relational knowledge and the "fix". Also, in the search for care, family members negotiated with their children's deficiencies and their meanings.

“...we feel the glances, right? Then I say: I'm going to get a microphone here and let people know that my daughter doesn't normally eat through the mouth, she eats through the gastro..." (M8) 
In the negotiation of what it is to be human, we observed that parents went from the private to the public to negotiate the recognition of their children's existence. The mothers attributed a sacred meaning to the care of their children's deficient bodies, which they assumed by a divine mission, where "God gave it to me, I have to take care" (M8). These bodies that constituted them were rare and, therefore, precious, unique to them. They contained inaccessible and enigmatic parts (the technologies), which they were afraid others would touch. They faced this care with courage, "shooting everywhere" (M1), and, even with all the suffering, they did not spare efforts and were fully committed to the cause.

Disabilities and living with disabilities marked the TI of families and their chronically complex children, in which "besides the experience of oppression by the disabled body, showed a convergence of other inequality variables, such as race, gender, sexual orientation, or age" (DINIZ, 2007) (p.61). In the field, we had the mothers as the primary caregivers (relatives responsible for helping the children in their daily care, such as administering medication, carrying out procedures, and monitoring visits and hospitalizations (ALVES et al., 2018)), and in few situations, the grandmother. This care is seen as a female task, restricted to the private life setting, and made even more vulnerable mothers/sisters/grandparents who performed this job and had to abandon their lives to live for the children. These completely absorbed caregivers were "the arms and legs" (M5) of their children.

The conditions of these mothers taking care of their children at home were as poor as those they faced in the public sphere. Society denies the value and relevance of care - which ends up becoming invisible - not for the tasks themselves but for the subjects who perform them (BIROLI, 2015). Therefore, due to the sexual division of domestic work, women are responsible for taking care of the family, oppressed by the good mother's myth (NEVES; CABRAL, 2008), which helps to justify and naturalize inequalities. They thus need to be recognized - good mothers and for this reason, they tend to suppress all their other identities in favor of the maternal identity, and their time concentrates on caring for the family (BIROLI, 2015; NEVES; CABRAL, 2008). Consequently, their possibilities of access to paid work and the opportunities for self-development, study, professionalization, and engagement in political life decrease (BIROLI, 2015; NEVES; CABRAL, 2008). The gender approach is essential in the analysis of current forms of care. However, in care with privatized and commodified perspectives, one cannot fail to consider 
that gender inequalities are connected with ethnicity and class, making women, black, and the poor more vulnerable (BIROLI, 2015).

Also experienced as blurring across borders, in TIs, families negotiated the hybrid and paradoxical aspects of their lives, constantly constructing what they are.

"I just have a report in my hand that she has hydranencephaly and meningitis...they say she has practically no brain...I look at her, and I don't see that, because she is very active..." (M6)

These negotiations were supported by their bodies, expressing the complexity of care that made their lives possible. With their ostomies - orifices surgically made in various organs that communicate the internal organ with the outside, for various reasons, whose purpose is to promote life - were, as advocated by Haraway (HARAWAY et al., 2013), living proof of that opposites are indistinct. With them, it became clear that what is outside is inside and vice versa. Not only in their ostomies and wounds, through which we contact their organs and secretions, but also when children who previously only survived in hospitals start to go home. Furthermore, there, they grow up and become adolescents. Their external world invades the interior of hospitals, and they take the hospital into their homes and bodies. These children and their caregivers are constantly producing what they are, through their relationships with each other, with other people, and with technology. In a setting of dependencies, they negotiate what it is "to be human". In this context, the subjects are looking not only for merely individual diagnoses but spaces for negotiations and meetings between people and society where, for these children and their families to exist, they need to go from the private to the public and negotiate.

In these new experiences of illness, the objectification of suffering led to the guarantee of rights, where fighting to be recognized as a patient involved technical knowledge about one's health condition and through medical reports, which emerged as new actors. We observed a significant movement related to rights: reports that ensure these subjects the Continuous Cash Benefit of the Organic Law of Social Assistance, medications, materials for handling the devices, declarations to justify absence at work and school. We also noticed the effort for inclusion, expressed mainly in the battles fought over the right of their children to attend school and the difficulties of transport. All mothers were engaged in the medical treatment of their children, following up with various experts in different places, the required hospitalizations, surgeries, and multiple home care, including the 
daily care of a dependent child, managing technologies and their complications, and therapies geared to children.

It is essential to point out that, despite having approached diagnosis and TI separately, they were actually correlated and had common aspects. We observed that diagnoses and TIs influenced and were influenced by the identities of the subjects involved in them. We understand identity (DUBAR, 1997) as a dynamic, timeand-space-dependent process, resulting from a negotiation between how the subject sees himself and how he is seen by society, which may or may not agree with his belonging and attribution identities. Diagnoses and TIs were performed (MOL, 2002) through space-and-time-dependent negotiation flows between the various human and non-human actors involved (LATOUR, 2012). Non-human actors were necessary, as they interfered in clinical definitions and routes seeking care, leading to actions that established the diagnoses and the TIs.

All these negotiations crossed the fight for the assured existence of these children, where family members incorporated several roles in constant construction in the time and spaces they covered. In this struggle, they negotiated with access to treatments and services, learning how to care for their children, their livelihood, the discrimination of their children, and managing technologies and their complications.

\section{Conclusion}

The health condition marks of the children observed, which concerned their diagnoses and the technologies they were dependent on, influenced the negotiations regarding their diagnoses and the negotiations observed in the TIs. Negotiations in the care of these children occurred among the different human and non-human actors involved. This process was established and forged the identities of the related people since the negotiations depended on where and when the interactions occurred between the actors. Depending on the spaces and times of interaction, the subjects assumed different identities in this negotiation. Care, therefore, was built through negotiation networks involving an organization of the lives of people related to it, where negotiations were related to the uncertainties inherent to the health condition and the possibilities of living with that diagnosis.

Thus, the negotiations in the care provided to these children denoted the construction of possibilities within a setting of suffering and uncertainty. Children and adolescents were established through their diagnoses and TIs. However, they 
were not limited to them, opening space for creativity in this experience, where the actors negotiated with each other, with themselves, and with society.

\section{References}

ALVES, C. A. Tessituras do cuidado: as condiçóes crônicas de saúde na infância e adolescência. Rio de Janeiro, RJ: Editora FIOCRUZ, 2016.

ALVES, P. C. A experiência da enfermidade: consideraçöes teóricas. Cad Saude Publica, v. 9, n. 3, p. 263-71, 1993.

ALVES, S. P. et al. The profile of caregivers to pediatric patients with cystic fibrosis. Ciência Samp; Saude Coletiva, v. 23, n. 5, p. 1451-1457, maio 2018.

ANÉAS, T. DE V.; AYRES, J. R. C. DE M. Significados e sentidos das práticas de saúde: a ontologia fundamental e a reconstrução do cuidado em saúde. Interface - Comunicação, Saúde, Educação, v. 15, n. 38, p. 651-662, set. 2011.

AYRES, J. R. DE C. M. Care and reconstruction in healthcare practices. Interface-Comunicação, Saúde, Educação, v. 8, n. 14, p. 73-92, fev. 2004 a.

AYRES, J. R. DE C. M. Care, (the) human being and health practices. Saúde e Sociedade, v. 13, n. 3, p. 16-29, dez. 2004b.

BARSAGLINI, R. A. As representações sociais e a experiência com o diabetes: um enfoque socioantropológico. Rio de Janeiro, RJ: Editora Fiocruz, 2011.

BECKER, H. S. Métodos de pesquisa em ciências sociais. São Paulo: Hucitec, 1994.

BIROLI, F. Responsabilidades, cuidado e democracia. Revista Brasileira de Ciência Política, n. 18, p. 81-117, dez. 2015.

BONET, O. Saber e sentir: uma etnografia da aprendizagem da biomedicina. Rio de Janeiro, RJ: Editora Fiocruz, 2004.

CAPRARA, A.; LANDIM, L. P. Etnografia: uso, potencialidades e limites na pesquisa em saúde. Interface - Comunicação, Saúde, Educação, v. 12, n. 25, p. 363-376, jun. 2008.

CASTRO, B. D. S. M. D.; MOREIRA, M. C. N. (Re)conhecendo suas casas: narrativas sobre a desospitalização de crianças com doenças de longa duração. Physis: Revista de Saúde Coletiva, v. 28, p. e280322, 14 jan. 2019.

COHEN, E. et al. Children With Medical Complexity: An Emerging Population for Clinical and Research Initiatives. Pediatrics, v. 127, n. 3, p. 529-538, 1 mar. 2011.

DA MATTA, R. O ofício de etnólogo, ou como ter "anthropological blues”. In: A aventura sociológica: objetividade, paixâo, improviso e método na pesquisa social E. O. Nunes (Org.). Rio de Janeiro, RJ: Zahar, 1978. p. 23-35. 
DINIZ, D. O que é deficiência. 1a ed. São Paulo, SP: Brasiliense, 2007.

DUARTE, J. G. et al. Perfil dos pacientes internados em serviços de pediatria no município do Rio de Janeiro: mudamos? Physis (Rio J.), p. 199-214, 2012.

DUARTE, M. C. S.; MOREIRA, M. C. N. Autonomia e cuidado em terapia intensiva pediátrica: os paradoxos da prática. Interface - Comunicação, Saúde, Educação, v. 15, n. 38, p. 687-700, 30 set. 2011.

DUBAR, C. A socialização: construção das identidades sociais e profissionais. Portugal: Porto, 1997. FAVERO-NUNES, M. A.; SANTOS, M. A. DOS. Itinerário terapêutico percorrido por mães de crianças com transtorno autístico. Psicologia: Reflexão e Crítica, v. 23, n. 2, p. 208-221, 2010. FERNANDEZ, H. G. C. et al. Tomando decisóes na atenção à saúde de crianças/adolescentes com condiçôes crônicas complexas: uma revisão da literatura. Ciênc. saúde coletiva, v. 24, n. 6, p. 2279-2292, jun. 2019.

FEUDTNER, C.; DIGIUSEPPE, D. L.; NEFF, J. M. Hospital care for children and young adults in the last year of life: a population-based study. BMC medicine, v. 1, p. 3, 23 dez. 2003. FOOTE-WHYTE, W. Treinando a observação participante. In: Desvendando máscaras sociais. [s.l: s.n.]. v. 2p. 77-86.

GASTALDO, É. Erwing Goffman. In: ROCHA, E.; FRID, M. (Eds.). . Os Antropólogos: Clássicos das Ciências Sociais. Petropolis (RJ): Vozes, 2015. p. 240 a 250.

GAVAZZA, C. Z. et al. Utilização de serviços de reabilitação pelas crianças e adolescentes dependentes de tecnologia de um hospital materno-infantil no Rio de Janeiro, Brasil. Cad Saude Publica, p. 1103-1111, 2008.

GEERTZ, C. A interpretação das culturas. Rio de Janeiro: LTC Editora, 1989.

GOFFMAN, E. Estigma: notas sobre a manipulação da identidade deteriorada. 3a. ed. Rio de Janeiro: Zahar, 1980.

GOMES, R. Análise e interpretação de dados de pesquisa qualitativa. In: DESLANDES, S. F. (Ed.). . Pesquisa social. Petrópolis: Editora Vozes, 2011.

GOODLEY, D.; RUNSWICK-COLE, K.; LIDDIARD, K. The DisHuman child. Discourse: Studies in the Cultural Politics of Education, v. 37, n. 5, p. 770-784, 2 set. 2016.

HARAWAY, D. J. et al. Antropologia do ciborgue: as vertigens do pós-humano. Belo Horizonte: Autentica, 2013.

JOSEPH, I. Erving Goffman e a Microssociologia. 1a ed. Rio de Janeiro: FGV, 2000.

JUTEL, A. Sociology of diagnosis: a preliminary review. Sociology of Health \& Illness, v. 31, n. 2, p. 278-299, mar. 2009. 
KLEINMAN, A.; BENSON, P. Culture, moral experience and medicine. The Mount Sinai Journal of Medicine, New York, v. 73, n. 6, p. 834-839, out. 2006.

LALLEMENT, M. História das idéias sociológicas: de Parsons aos contemporâneos. Petrópolis: Vozes, 2004.

LAPLANTINE, F. Aprender antropologia. São Paulo (SP): Brasiliense, 1991.

LATOUR, B. Reagregando o social. Salvador: Edufba, 2012.

MAGNANI, J. G. C. Insider and a close-up view: notes on urban ethnography. Revista Brasileira de Ciências Sociais, v. 17, n. 49, p. 11-29, jun. 2002.

MARTIN, D.; SPINK, M. J.; PEREIRA, P. P. G. Corpos múltiplos, ontologias políticas e a lógica do cuidado: uma entrevista com Annemarie Mol. Interface - Comunicação, Saúde, Educação, v. 22, n. 64, p. 295-305, mar. 2018.

MARTINS, C. B. C. O legado do Departamento de Sociologia de Chicago (1920-1930) na constituição do interacionismo símbólico. Sociedade e Estado, v. 28, n. 2, p. 217-239, ago. 2013.

MENEZES, R. A. Difíceis Decisões: uma abordagem antropológica da Prática Médica em CTI. Physis: Revista de Saúde Coletiva, v. 10, n. 2, p. 27-49, dez. 2000.

MENEZES, R. A. Em busca da boa morte: antropologia dos cuidados paliativos. Rio de Janeiro, RJ: Editora Fiocruz : Garamond, 2004.

MINAYO, M. C. DE S. Trabalho de campo: contexto de observação, interação e descoberta. In: Pesquisa social. Petrópolis: Editora Vozes, 2011.

MOL, A. The body multiple: ontology in medical practice. Durham: Duke University Press, 2002.

MOL, A. The logic of care: health and the problem of patient choice. London ; New York: Routledge, 2008.

MOL, A. The logic of care. Health care and the limits of choice. 2013. Disponível em: <http://gafc. khu.ac.kr/html_2013/scholarship/pdf/2011PBF/3.The\%20Body\%20and\%20Culture.pdf>.

MOREIRA, M. C. N. et al. Diagnóstico das condiçôes crônicas em pediatria no Instituto Fernandes Figueira/FIOCRUZ: retrato da morbidade hospitalar e linhas de cuidados. Rio de Janeiro: Fiocruz, 2015.

MOREIRA, M. C. N.; CUNHA, C. C.; MELLO, A. Conversando sobre as crianças e adolescentes com condicoes crônicas complexas: interfaces entre a atenção domiciliar e a atenção de media e alta complexidade. In: SANTOS, I. S.; GOLDSTEIN, R. A. (Eds.). . Rede de pesquisa em Manguinhos : sociedade, gestores e pesquisadores em conexão com o SUS. 1a. ed. São Paulo: Hucitec, 2016. p. 331.

MOURA, E. C. D. et al. Complex chronic conditions in children and adolescents: hospitalizations in Brazil, 2013. v. 0105/2016, 2016. 
NEVES, E. T.; CABRAL, I. E. Empoderamento da mulher cuidadora de crianças com necessidades especiais de saúde. Texto Samp; Contexto - Enfermagem, v. 17, n. 3, p. 552-560, set. 2008 .

PAEZ, A.; MOREIRA, M. C. N. Construçôes de maternidade: experiências de mães de crianças com síndrome do intestino curto. Physis: Revista de Saúde Coletiva, v. 26, n. 3, p. 1053-1072, set. 2016.

PINTO, A. M. S. Cultura e instituições de saúde: estudando a participação de traços culturais da sociedade brasileira no processo de trabalho de serviços de atenção básica. Cien Saude Colet [periódico na internet], 2010.

PRADO, A. M. O JEITINHO BRASILEIRO: UMA REVISAO BIBLIOGRÁFICA. Horizonte Cientifico, v. 10, n. 1, 7 out. 2016.

RANGEL, A. M. H. A DINÂMICA COTIDIANA DA NEGOCIAÇÃO DA ORDEM HOSPITALAR ENTRE PROFISSIONAIS DE SAÚDE EACOMPANHANTES DE CRIANÇAS INTERNADAS. doutorado-Rio de Janeiro: FIOCRUZ, 2007.

ROSENBERG, C. E. The tyranny of diagnosis: specific entities and individual experience. The Milbank Quarterly, v. 80, n. 2, p. 237-260, 2002.

RUSSELL, C. J.; SIMON, T. D. Care of children with medical complexity in the hospital setting. Pediatric Annals, v. 43, n. 7, p. e157-162, jul. 2014.

SIQUEIRA, S. M. C. et al. Itinerário terapêutico em situaçóes de urgência e emergência pediátrica em uma comunidade quilombola. Ciência \&amp; Saúde Coletiva, v. 21, n. 1, p. 179189, jan. 2016.

STRAUSS, A. L. Negotiations: varieties, contexts, processes, and social order. 1st ed. San Francisco: Jossey-Bass, 1978.

STRAUSS, A. L. et al. The work of hospitalized patients. Social Science \& Medicine, v. 16, n. 9, p. 977-986, jan. 1982.

VALLADARES, L. Os dez mandamentos da observação participante. Revista Brasileira de Ciências Sociais, v. 22, n. 63, p. 153-155, fev. 2007.

VELHO, G. Observando o familiar. In: Individualismo e Cultura - Notas para uma antropologia da Sociedade Contemporânea. 6a edição ed. Rio de Janeiro: Jorge Zahar Editor, 1999. p. 122-132. VENTURINI, E. A desinstitucionalização: limites e possibilidades. Journal of Human Growth and Development, v. 20, n. 1, p. 138-151, abr. 2010. 


\section{Resumo}

Negociaçóes no Cuidado de crianças

cronicamente adoecidas: construção de

possibilidades em um cenário de incertezas

Interessados em explorar a construção das negociaçóes presentes nas relaçóes de decisões no cuidado crônico complexo em pediatria em ambiente ambulatorial, acessamos Anselm Strauss e o conceito de ordem negociada e Annemarie Mol com o conceito das lógicas das decisóes associada à teoria ator-rede de Latour. Fizemos uso de uma perspectiva etnográfica da pesquisa em saúde nos ambulatórios de pediatria e estomaterapia de um hospital localizado na cidade do Rio de Janeiro, no período de julho a dezembro de 2017. A interpretação do campo convergiu para 2 grandes eixos: diagnóstico e itinerários terapêuticos, onde o cuidado foi performado por meio de redes de negociação. Estas disseram respeito à organização da vida das pessoas relacionadas a este cuidado. Todo este processo de negociação se deu num cenário híbrido, marcado por borramento entre fronteiras, onde os envolvidos com o cuidado negociavam constantemente o reconhecimento de suas crianças. $\mathrm{Na}$ dependência dos espaços e tempos de interação, os atores transitavam por diversas identidades, numa negociação entre como eles se reconheciam e como eram reconhecidos pelas pessoas no cuidado crônico complexo. As negociaçóes no cuidado observadas se deram entre as incertezas inerentes à condição de saúde e às possibilidades de viver com aquele diagnóstico.

> Palavras-chave: Negociação; cuidado da criança; doença crônica, etnografia. 